\title{
Preparation regimen is more important than patient-related factors: a randomized trial comparing a standard bowel preparation before colonoscopy with an individualized approach
}

\author{
T. VOIOSU ${ }^{1,2}$, ALINA TANȚĂU ${ }^{3,4}$, A. VOIOSU ${ }^{1,2}$, ANDREEA BENGUS ${ }^{1}$, CRISTINA MOCANU ${ }^{1}$, \\ BIANCA SMARANDACHE ${ }^{1}$, C. BAICUŞ ${ }^{1,2}$, IOANA VIŞOVAN $^{3}$, B. MATEESCU ${ }^{1,2}$ \\ "“Colentina" Clinical Hospital, Bucharest, Romania \\ ${ }^{2} \mathrm{UMF}$ "Carol Davila", Bucharest, Romania \\ ${ }^{3}$ Medical Centre of Gastroenterology, Hepatology and Digestive Endoscopy, Cluj-Napoca, Romania \\ ${ }^{4}$ UMF “Iuliu Haţieganu”, Cluj-Napoca, Romania
}

\begin{abstract}
Background. Optimal bowel preparation is one of the most important factors affecting the quality of colonoscopy. Several patient-related factors are known to influence the quality of bowel cleansing but randomized trials in this area are lacking. We aimed to compare an individualized bowel prep strategy based on patient characteristics to a standard preparation regimen.

Material and Methods. We conducted an endoscopist-blinded multicenter randomized control-trial. The Boston Bowel Prep Score (BBPS) was used to assess quality of bowel preparation and a 10 point visual analogue scale to assess patient comfort during bowel prep. Patients were randomised to either the standard regimens of split-dose 4L polyethylene-glycol (group A), split-dose sodium picosulphate/magnesium citrate (group B) or to either of the two depending on their responses to a 3-item questionnaire (individualized preparation, group $\mathrm{C}$ ).

Results. 185 patients were randomized during the study period and 143 patients were included in the final analysis. Patients in the individualized group had a median BBPS of 7 compared to a median of 6 in the standard group $(p=0.7)$. Also, there was no significant difference in patients' comfort scores, irrespective of study group or laxative regimen. However, on multivariable analysis, a split-dose 4L polyethylene-glycol was an independent predictor for achieving a BBPS $>6$ (OR 3.7, 95\% CI 1.4-9.8), regardless of patient-related factors.

Conclusion. The choice of laxative seems to be more important than patient-related factors in predicting bowel cleansing. Comfort during bowel prep is not influenced by the type of strategy used.
\end{abstract}

Keywords: colonoscopy, bowel preparation, laxatives, randomized clinical trial, polyethylene glycol.

\section{INTRODUCTION}

Adequate bowel preparation is essential in colonoscopy because both adenoma detection rate (ADR) and caecal intubation rate (CIR) are affected by poor bowel cleansing $[1,2]$. Suboptimal bowel preparation is associated with an increased risk of missed lesions and need for earlier reevaluation $[3,4]$. As a result, the quality of bowel cleansing has become a key quality indicator in itself, with a $90 \%$ rate of adequate preparations currently being recommended for colonoscopy-based screening programs [5].

Several predictors of inadequate bowel preparation have been highlighted by previous studies, including lower socioeconomic status, chronic constipation, in-patient status, concomitant medication (tricyclic antidepressants or opioids) and patient non-compliance to instructions on bowel prep [6-8]. Furthermore, many patients consider bowel cleansing itself to be the most difficult part of the colonoscopy process [9].

Despite the multitude of studies comparing different laxative solutions and preparation schedules [10-13], there are no randomized trials examining the potential value of bowel preparation regimens individualized according to relevant patient features or preferences and most patients receive a standard preparation regimen in accordance to available guidelines and local practice and drug availability. There is, however, an increasing body of data suggesting that distinct patient groups might benefit from a personalized preparation regimen (i.e. low-volume regimens) with similar efficiency in bowel cleansing, but increased tolerability [14]. Our aim was to evaluate the role of an individualized bowel cleansing strategy in increasing the quality and tolerability of conventional bowel prep regimens. 


\section{MATERIAL AND METHODS}

We conducted a single-blind randomized control-trial (clinical trials. gov NCT02024022) in two tertiary referral centers for colonoscopy ("Colentina" Clinical Hospital, Bucharest and the Medical Center for Gastroenterology, Hepatology and Endoscopy, Cluj) between January 2014 and June 2015. All out-patients older than 18 years of age undergoing their first colonoscopy were considered eligible for participation, irrespective of the indication for the procedure. Exclusion criteria consisted of refusal to sign the informed consent, pregnancy or any severe coexisting conditions (i.e. heart or kidney failure, liver cirrhosis, respiratory failure, severe neurological or psychiatric conditions requiring chronic therapy such as but not limited to opioid or tricyclic antidepressants) which were deemed to interfere with an adequate bowel preparation process.

The study was approved by the local ethics committee at each institution and conducted in accordance to the principles of the Declaration of Helsinki.

\section{Bowel preparation strategies}

Our aim was to compare a standard preparation strategy using either $4 \mathrm{~L}$ polyethyleneglycol (PEG) or sodium phosphate/magnesium citrate (SP/MC) with an individual strategy where patients were allocated to PEG or SP/MC based on a predefined set of criteria. Patients were randomized 1:1:2 and allocated to $4 \mathrm{~L}$ split-dose PEG (group A), split-dose SP/MC (group B) or to the individualized prep group (group C) by a physician who was not involved in the endoscopic procedures by the use of sequentially numbered opaque sealed envelopes. Patients in group $\mathrm{C}$ received either $4 \mathrm{~L}$ split-dose PEG or SP/MC based on their responses to a 3 -item questionnaire regarding education level, selfassessed tolerance of a large volume preparation regimen ( $>3$ liters) and history of constipation and/or laxative use over the last three months (Table 1). The questionnaire was designed to include the three most significant patient-related factors likely to influence bowel prep quality based on data from our previous pilot study [15] and a review of the available literature.

Table 1

Decision algorithm for selecting an individualized preparation regimen in patients randomized to Group $\mathrm{C}^{*}$

\begin{tabular}{lcc}
\hline & Answer favoring PEG & Answer favoring SP/MC \\
\hline Higher education (college or equivalent) & Yes & No \\
$\begin{array}{l}\text { History of constipation/ laxative use in the past } 3 \text { months } \\
\begin{array}{l}\text { Self-assessed capability of completing a large-volume } \\
\text { preparation (over } 3 \text { liters of ingested fluid) }\end{array}\end{array}$ & Yes & No \\
\hline
\end{tabular}

*a minimum of 2 out of 3 answers favoring a particular regimen were required in order to decide patient allocation to either PEG or SP/MC.

Patients in the PEG arms of the study were instructed to ingest 2L of PEG (Fortrans, BeaufourIpsen ${ }^{\circledR}$ ) between $6-8 \mathrm{pm}$ in the evening and $2 \mathrm{~L}$ of PEG between 6-8 am in the morning of the examination. Patients in the SP/MC group received 1 dose of Picoprep (Ferring Pharmaceuticals ${ }^{\circledR}$ ) at 8 $\mathrm{pm}$ in the evening and the second dose at $6 \mathrm{am}$ in the morning of the examination; patients were instructed to ingest around an additional $250 \mathrm{~mL}$ clear liquid/hour between 7 and $10 \mathrm{pm}$ in the evening before the examination and between 5 and $8 \mathrm{am}$, amounting to approximately $2.5 \mathrm{~L}$ of liquid ingested, including the study drug. A light lunch was allowed on the day prior to colonoscopy, but no other special dietary restrictions were recommended. All patients received standard brochures on bowel cleansing according to the manufacturer's instructions and were scheduled for morning colonoscopies ( $9 \mathrm{am}-1 \mathrm{pm})$ in the participating clinics.

\section{Study Outcomes}

The main outcome was the quality of the bowel preparation and the secondary outcome consisted of the comfort score reported by the patient after completing the bowel preparation process, prior to colonoscopy.

\section{Outcome assessment}

Bowel preparation was assessed by experienced endoscopists ( $>500$ procedures) blinded to the preparation regimen, using the Boston Bowel Preparation Scale (BBPS) which grades individual segments of the bowel on a scale of $0-3$ for a maximum possible total of 9 points, with higher scores reflecting better preparation; this was further described as adequate at a cut-off value of 6 or higher of the BBPS $[16,17]$.

Patients reported the degree of comfort during the bowel preparation with the aid of a visual 
analog scale from 0 to 10 , with higher scores reflecting increased discomfort during bowel preparation.

\section{STATISTICAL ANALYSIS}

\section{Sample size calculation}

We based our sample size calculation on a 1 point difference in mean bowel prep scores between the two preparation strategies (individualized versus non-individualized) with a SD of 1.5 points, a power of $80 \%$ and an alpha value of $5 \%$. This hypothesis was based on data from our previous pilot study [15]. We calculated that 65 patients were required per group (130 in total) and allowed for an estimated $20 \%$ drop-off rate resulting in a total of 156 patients estimated for achieving adequate statistical power.

\section{Data recording and analysis}

SPSS 16 (Chicago, Illinois) was used for data recording and analysis.

Examinations with incomplete bowel preparation scores as well as incomplete examinations (e.g. stenosing colorectal tumors preventing colonoscope insertion) were not included in the final perprotocol analysis.

Results are reported as means and standard deviations for variables with a normal distribution and median, minimum and maximum respectively for variables with a nonnormal distribution. We conducted univariable analysis using nonparametric tests (Mann Whitney U and Kruskall Wallis) to compare bowel prep quality and patient comfort between strategies and across treatment groups. For multiple comparisons, the Bonferroni correction was used. We also conducted multivariable analysis using logistic regression to analyze factors influencing bowel prep quality. Variables in the final regression model were also tested for 2-way interactions to further explore the relationship between them. Results were considered statistically significant at a $\mathrm{p}$ value $<0.05$.

\section{RESULTS}

One hundred eighty-five subjects were randomized between January 2014 and June 2015 at the two participating institutions; 143 patients completed the study and were included in the final analysis (Figure 1). The characteristics of the three study groups are further detailed in Table 2.

\section{Bowel preparation quality}

There was no statistically significant difference between the study groups with regard to bowel prep quality when comparing the individualized strategy (group C) to the standard strategy (groups A+B), with 51 out of 69 (73.9\%) patients achieving a score of 6 or higher on the BBPS compared to 52 out of $74(70.7 \%)$ in the standard group $(\mathrm{p}=$ 0.7 Chi Square) (Table 3).

However, when comparing individual groups of patients, there was a statistically significant difference in total Boston scores and left colon Boston scores (Table 4). This difference was due to a statistically significant difference between groups $\mathrm{A}$ and $\mathrm{B}$ with regard to left colon and total Boston scores favoring group $A(p=0.002$ and $p=0.03$ Mann Whitney U, statistically significant after applying the Bonferroni correction for multiple comparisons).

When analyzing across all study groups, patients using a 4L split-dose PEG had higher overall BBPS compared to patients using SP/MC, with a median BBPS of 7 and 6 respectively $(p=$ 0.002 Mann Whitney U).

Table 2

Characteristics of the subjects in each study group

\begin{tabular}{lccc}
\hline & $\begin{array}{c}\text { Standard Preparation Strategy } \\
\text { (Groups A+B) }\end{array}$ & $\begin{array}{c}\text { Individualized Strategy } \\
\text { (Group C) }\end{array}$ \\
\hline Mean Age (SD) & Group A (n=37) & Group B (n=37) & Group C (n=69) \\
Female (total) & $58(11)$ & $57(14)$ & $54(15)$ \\
Indication for colonoscopy & $18(37)$ & $22(37)$ & $40(69)$ \\
Screening & & & 11 \\
Anemia & 9 & 4 & 4 \\
Visible blood & 4 & 1 & 18 \\
Surveillance & 8 & 9 & 1 \\
Chronic Diarrhea & 1 & 0 & 10 \\
Other & 2 & 9 & 24 \\
\hline
\end{tabular}






Figure 1. CONSORT flowchart of patients enrolled in the study.

Table 3

Comparison of Boston scores and subscores between the two strategies

\begin{tabular}{lccc}
\hline \multicolumn{1}{c}{ Boston Score } & $\begin{array}{c}\text { Individualized strategy } \\
\text { (Group C) }\end{array}$ & $\begin{array}{c}\text { Standard preparation } \\
\text { (Group A+B) }\end{array}$ & P \\
\hline Total Score & $7(2-9)$ & $6(0-9)$ & 0.68 \\
Left colon & $2(0-3)$ & $2(0-3)$ & 0.98 \\
Transverse colon & $2(1-3)$ & $2(0-3)$ & 0.93 \\
Right colon & $2(0-3)$ & $2(0-3)$ & 0.34 \\
\hline
\end{tabular}


Table 4

Comparison of Boston Scores and subscores according to study groups

\begin{tabular}{lcccc}
\hline \multicolumn{1}{c}{ Boston Score } & $\begin{array}{c}\text { Group A } \\
\text { (PEG) }\end{array}$ & $\begin{array}{c}\text { Group B } \\
\text { (SP/MC) }\end{array}$ & Group C (Individualized) & p \\
\hline Total Score & $7(2-9)$ & $6(0-9)$ & $7(2-9)$ & $\mathbf{0 . 0 4 3}$ \\
Left colon & $3(1-3)$ & $2(0-3)$ & $2(0-3)$ & $\mathbf{0 . 0 0 7}$ \\
Transverse colon & $2(0-3)$ & $2(0-3)$ & $2(1-3)$ & 0.15 \\
Right colon & $2(0-3)$ & $2(0-3)$ & $2(0-3)$ & 0.4 \\
\hline
\end{tabular}

I- using Kruskall-Wallis

\section{Patient comfort}

Median reported comfort score was 3 across the entire study cohort, with $26(18 \%)$ of subjects reporting no discomfort caused by the bowel prep procedure. There was no statistically significant difference in median patient comfort scores between study groups ( $p=0.2$ Kruskall Wallis) or between the individualized and standard strategies $(\mathrm{p}=0.5$ Mann Whitney U). The most frequent complaint related to the bowel preparation was nausea (31\%), followed by abdominal pain and cramps $(29 \%)$, with no statistically significant difference between study groups and strategies. No serious adverse event related to the bowel prep or the procedure was reported during the study period.

\section{Multivariable analysis}

The use of a 4L split-dose PEG preparation was the only factor associated with a significantly higher rate of adequate bowel preparation defined as a $\mathrm{BBPS} \geq 6(\mathrm{OR}=3.7,95 \%$ CI $1.4-9.8)$. There was no statistically significant effect of gender, age, body-mass index or bowel prep strategy on bowel prep quality in our multivariable model (Table 5).

Table 5

Factors influencing bowel preparation on multivariate analysis (logistic regression)

\begin{tabular}{lcc}
\hline \multicolumn{1}{c}{ Factor } & Odds Ratio & $\mathbf{9 5 \%}$ Confidence interval \\
\hline 4L PEG & $\mathbf{2 . 5}$ & $\mathbf{1 . 1 - 5 . 7}$ \\
BMI & 0.98 & $0.9-1.1$ \\
Standard Strategy & 0.8 & $0.3-2$ \\
Age & 1.01 & $0.9-1.1$ \\
Male gender & 1.6 & $0.6-4.5$ \\
Reported adherence & 0.7 & $0.06-8$ \\
Comfort score & 0.9 & $0.8-1.1$ \\
\hline
\end{tabular}

- statistically significant at a 0.05 level

\section{DISCUSSION}

To our knowledge this is the first randomized clinical trial assessing the value of an individualized bowel prep strategy based on relevant patient features determined via a standardized selfadministered questionnaire. Several studies have addressed patient-related characteristics as predictors of bowel prep quality $[8,18-20]$, but to date no randomized studies have explored the potential to optimize bowel preparation using such factors. We hypothesized that including patient-specific information in the physician's choice of prescribed bowel prep regimen would increase the cleanliness of the colon and thus the quality of the colonoscopy.

Our choices for comparison of bowel prep regimens were based on current ESGE guidelines that recommend a split-dose 4L PEG as the gold standard for bowel preparation with the alternative of a low-volume preparation using SP/MC or PEG, especially for elective colonoscopies in an outpatient setting [14]. However, while both SP/MC and PEG regimens are widely considered to yield satisfactory cleansing when used in a split-dose manner [21, 22], it is generally accepted that lowvolume preparations, including $\mathrm{SP} / \mathrm{MC}$, are better tolerated by patients $[13,15]$.

The three factors we included in our questionnaire were patient education status, history of constipation and/or laxative use in the past 3 months and self-assessed tolerability of adhering to a large-volume regimen such as the 4L PEG.

Chronic constipation is a common condition in patients undergoing colonoscopy and has been traditionally associated with poor bowel prep [23, 24]. The role of socioeconomic status and patient 
education levels have been extensively explored in relationship to bowel preparation quality with lower education levels and poor socioeconomic status identified as predictors of inadequate bowel prep [25-27]. Since our pilot study [15] also suggested that patients who were better educated and had a higher self-reported adherence to the preparation instructions were more likely to have better cleansing using the split-dose 4L PEG than an SP/MC regimen, we also included these 2 criteria in our selection tool for the individualized bowel prep regimen.

The main innovation in our study was the use of a standardized 3-item questionnaire designed to select patients who were more likely to benefit from a low-volume SP/MC based preparation. Based on our earlier pilot-study [15] and data from the literature, we hypothesized that individualizing bowel regimens according to patient-related factors would increase patient satisfaction and the likelyhood of correct preparation of the colon. However, our RCT failed to show the superiority of an individualized strategy over the conventional use of 4L PEG and SP/MC regimens with regard to bowel preparation quality. Furthermore, multivariable analysis showed that the only predictor for a better preparation across all study groups was the use of a split-dose 4L PEG regimen, regardless of patientrelated factors such as age, BMI, history of constipation, education levels and self-reported adherence to instructions.

The main limitation of our study is the fact that only first-time examinations of out-patients were eligible for inclusion, potentially limiting the applicability of our results in a wider population setting. Also, we acknowledge the fact that some other patient related factors reported in previous studies (i.e. chronic use of opioids or antidepressants, coexisting diabetes and neurological conditions) were not taken into account due to the study design and might further restrict the generalization of our results. However, we consider that, for an outpatient population as was the case in our study, these factors might be less relevant than for inpatients who are more likely to have multiple and severe coexisting conditions.

The advent of nation-wide colonoscopybased colorectal cancer screening programs makes proper colonoscopy preparation essential and, as such, adapting the choice of bowel prep agent to individual requirements might improve the efficacy of the programs and the compliance of the patients. Our data shows that the use of $4 \mathrm{~L}$ split-dose PEG is superior to SP/MC in providing a cleaner colon and a comfortable bowel preparation process, and the overall benefit seems to be related to a superior cleansing of the left colon (Table 4). This is in accordance with recommendations from the ESGE which consider the 4L split-dose PEG regimen the gold standard, offering optimum preparation with minimal adverse events. The failure of our individualized strategy to improve overall bowel cleansing might reflect the fact that preparationrelated factors such as the type of laxative used, the volume of liquid ingested and the timing of the preparation outweigh patient-related factors in their impact on bowel preparation. However, due to the inherent limitations of our study, we believe further research is needed in the effort to optimize the process of bowel preparation and assign individual patients the best suited preparation regimen for their particular needs.

Acknowledgements. The authors would like to thank Bogdan Busuioc MD and Mihai Rimbas PhD for helping with patient recruitment.

Introducere. Curățarea adecvată a colonului pentru colonoscopie este unul dintre factorii cheie care influențează calitatea examinării endoscopice. Mai mulți factori legați de pacient determină calitatea pregătirii dar lipsesc studiile randomizate in acest domeniu. Obiectivul nostru a fost compararea unei strategii standard de pregătire pentru colonoscopie cu o strategie individualizată, ținând cont de caracteristicile pacientului.

Materiale şi Metode. Am desfăşurat un studiu randomizat multicentric simplu-orb. Scala Boston (BBPS) a fost utilizată pentru aprecierea calității pregătirii şi o scală analog vizuală cu 10 puncte a fost folosită pentru a evalua confortul pacienților în timpul pregătirii. Pacienții au fost randomizați către regimuri standard cu administrare in 2 doze folosind $4 L$ de polietilen glicol (grupul A) sau o combinație de picosulfat de sodiu şi citrat de magneziu (grupul B), sau către un regim individualizat, cu una din cele 2 scheme alese in funcție de răspunsurile la un chestionar cu 3 întrebări (grup C, pregătire individualizată). 
Rezultate. 185 de pacienți au fost randomizați şi 143 au fost incluşi în analiza finală. Pacienții din grupul individualizat au avut un scor Boston asemănător cu cel din grupul standard (mediana 7 vs. mediana 6, $p=0.7$ ). Nu s-a decelat nicio diferență semnificativă între scorurile de confort, indiferent de grupul de studiu sau regimul laxativ. Totuşi, la analiza multivariată, regimul cu $4 L$ PEG a fost predictor independent al unui scor Boston >6 (OR 3.7, 95\% CI 1.4-9.8), indiferent de factorii legați de pacient.

Concluzii. Alegerea regimului laxativ pare a fi mai importantă decât factorii legați de pacient în predicția gradului de curățare a colonului. Confortul pacienților nu pare a fi influențat de strategia utilizată.

Correspondence to: Theodor Voiosu, MD, PhD, Gastroenterology Department, "Colentina" Clinical Hospital, 19-21 Ştefan cel Mare Bvd, Bucharest, Romania, Tel/fax: 0040213180604

E-mail: theodor.voiosu@gmail.com

\section{REFERENCES}

1. PULLENS HJ, SIERSEMA PD. Quality indicators for colonoscopy: Current insights and caveats. World J Gastrointest Endosc. 2014, 16; 6(12):571-83.

2. JOHNSON DA, BARKUN AN, COHEN LB, DOMINITZ JA, KALTENBACH T, MARTEL M AND THE US MULTISOCIETY TASK FORCE ON COLORECTAL CANCER. Optimizing adequacy of bowel cleansing for colonoscopy: recommendations from the US Multi-Society Task Force on Colorectal Cancer. Am J Gastroenterol. 2014; 109(10):1528-45.

3. LEBWOHL B, KASTRINOS F, GLICK M, ROSENBAUM AJ, WANG T, NEUGUT AI. The impact of suboptimal bowel preparation on adenoma miss rates and the factors associated with early repeat colonoscopy. Gastrointest Endosc. 2011; 73(6):1207-14.

4. FROEHLICH F., WIETLISBACH V., GONVERS J.J., BURNAND B, VADER JP. Impact of colonic cleansing on quality and diagnostic yield of colonoscopy: the European Panel of Appropriateness of Gastrointestinal Endoscopy European Multicenter Study. Gastrointest Endosc 2005; 61: 378-84.

5. REMBACKEN B, HASSAN C, RIEMANN JF, CHILTON A, RUTTER M, DUMONCEAU JM, OMAR M, PONCHON T. Quality in screening colonoscopy: position statement of the European Society of Gastrointestinal Endoscopy (ESGE). Endoscopy. 2012; 44(10):957-68.

6. YADLAPATI R, JOHNSTON ER, GREGORY DL, CIOLINO JD, COOPER A, KESWANI RN. Predictors of Inadequate Inpatient Colonoscopy Preparation and Its Association with Hospital Length of Stay and Costs. Dig Dis Sci. 2015; 60(11):3482-90.

7. MENEES SB, KIM HM, WREN P, ZIKMUND-FISHER BJ, ELTA GH, FOSTER S, KORSNES S, GRAUSTEIN B, SCHOENFELD P. Patient compliance and suboptimal bowel preparation with split-dose bowel regimen in average-risk screening colonoscopy. Gastrointest Endosc. 2014; 79(5):811-820.e3.

8. NESS RM, MANAM R, HOEN H, CHALASANI N. Predictors of inadequate bowel preparation for colonoscopy. Am J Gastroenterol 2001; 96:1797-1802.

9. KO CW, RIFFLE S, SHAPIRO JA, SAUNDERS MD, LEE SD, TUNG BY, KUVER R, LARSON AM, KOWDLEY KV, KIMMEY MB. Incidence of minor complications and time lost from normal activities after screening or surveillance colonoscopy. Gastrointest Endosc 2007; 65: 648-56.

10. BELSEY J, CROSTA C, EPSTEIN O, FISCHBACH W, LAYER P, PARENTE F, HALPHEN M. Meta-analysis: the relative efficacy of oral bowel preparations for colonoscopy 1985-2010. Aliment Pharmacol Ther. 2012; 35(2):222-37.

11. PARK SS, SINN DH, KIM Y-H, LIM YJ, SUN Y, LEE JH, KIM JY, CHANG DK, SON HJ, RHEE PL, RHEE JC, KIM JJ. Efficacy and tolerability of split-dose magnesium citrate: low-volume (2 liters) polyethylene glycol vs. single- or split-dose polyethylene glycol bowel preparation for morning colonoscopy. Am J Gastroenterol 2010; 105: 1319-26.

12. KOJECKY V, DOLINA J, KIANICKA B, MISUREC M, VARGA M, LATTA J, VACULIN V. A single or split dose picosulphate/magnesium citrate before colonoscopy: comparison regarding tolerance and efficacy with polyethylene glycol. A randomized trial. J Gastrointestin Liver Dis. 2014; 23(2):141-6.

13. MUNSTERMAN ID, CLEEREN E, VAN DER PLOEG T, BROHET R, VAN DER HULST R. "Pico-Bello-Klean study": effectiveness and patient tolerability of bowel preparation agents sodium picosulphate-magnesium citrate and polyethylene glycol before colonoscopy. A single-blinded randomized trial. Eur J Gastroenterol Hepatol. 2015; 27(1):29-38.

14. HASSAN C, BRETTHAUER M, KAMINSKI MF, POLKOWSKI M, REMBACKEN B, SAUNDERS B, BENAMOUZIG R, HOLME O, GREEN S, KUIPER T, MARMO R, OMAR M, PETRUZZIELLO L, SPADA C, ZULLO A, DUMONCEAU JM; European Society of Gastrointestinal Endoscopy. Bowel preparation for colonoscopy: European Society of Gastrointestinal Endoscopy (ESGE) guideline. Endoscopy. 2013; 45(2):142-50.

15. VOIOSU T, RATIU I, VOIOSU A, IORDACHE T, SCHIPOR A, BAICUS C, SPOREA I, VOIOSU R. Time for individualized colonoscopy bowel-prep regimens? A randomized controlled trial comparing sodium picosulphate and magnesium citrate versus 4-liter split-dose polyethylene glycol. J Gastrointestin Liver Dis. 2013; 22(2):129-34.

16. CALDERWOOD AH, JACOBSON BC. Comprehensive validation of the Boston Bowel Preparation Scale. Gastrointest Endosc 2010; 72:686-692. 
17. CALDERWOOD AH, SCHROY PC 3RD, LIEBERMAN DA, LOGAN JR, ZURFLUH M, JACOBSON BC. Boston Bowel Preparation Scale scores provide a standardized definition of adequate for describing bowel cleanliness. Gastrointest Endosc. 2014; 80(2):269-76.

18. CHUNG YW, HAN DS, PARK KH, KIM KO, PARK CH, HAHN T, YOO KS, PARK SH, KIM JH, PARK CK. Patient factors predictive of inadequate bowel preparation using polyethylene glycol: a prospective study in Korea. J Clin Gastroenterol. 2009; 43(5):448-52.

19. LEBWOHL B, WANG TC, NEUGUT AI. Socioeconomic and other predictors of colonoscopy preparation quality. Dig Dis Sci. 2010; 55(7):2014-20.

20. YEE R, MANOHARAN S, HALL C, HAYASHI A. Optimizing bowel preparation for colonoscopy: what are the predictors of an inadequate preparation? Am J Surg. 2015; 209(5):787-92.

21. BUCCI C, ROTONDANO G, HASSAN C, REA M, BIANCO MA, CIPOLLETTA L, CIACCI C, MARMO R. Optimal bowel cleansing for colonoscopy: split the dose! A series of meta-analyses of controlled studies. Gastrointest Endosc. 2014; 80(4):566576.

22. MARTEL M, BARKUN AN, MENARD C, RESTELLINI S, KHERAD O, VANASSE A. Split-Dose Preparations Are Superior to Day-Before Bowel Cleansing Regimens: A Meta-analysis. Gastroenterology. 2015; 149(1):79-88.

23. ROTONDANO G, RISPO A, BOTTIGLIERI ME, DE LUCA L, LAMANDA R, ORSINI L, BRUZZESE D, GALLORO G; SIED Campania PISCoPO study group investigators. Quality of bowel cleansing in hospitalized patients undergoing colonoscopy: A multicentre prospective regional study. Dig Liver Dis. 2015; 47(8):669-74.

24. HAUTEFEUILlE G, LAPUELLE J, CHAUSSADE S, PONCHON T, MOLARD BR, COULOM P, LAUGIER R, HENRI F, CADIOT G. Factors related to bowel cleansing failure before colonoscopy: Results of the PACOME study. United European Gastroenterol J. 2014; 2(1):22-9.

25. MODI C, DEPASQUALE JR, DIGIACOMO WS, MALINOWSKI JE, ENGELHARDT K, SHAIKH SN, KOTHARI ST, KOTTAM R, SHAKOV R, MAKSOUD C, BADDOURA WJ, SPIRA RS. Impact of patient education on quality of bowel preparation in outpatient colonoscopies. Qual Prim Care. 2009; 17(6):397-404.

26. CHANG CW, SHIH SC, WANG HY, CHU CH, WANG TE, HUNG CY, SHIEH TY, LIN YS, CHEN MJ. Meta-analysis: The effect of patient education on bowel preparation for colonoscopy. Endosc Int Open. 2015; 3(6):E646-52.

27. YADLAPATI R, JOHNSTON ER, GREGORY DL, CIOLINO JD, COOPER A, KESWANI RN. Predictors of inadequate inpatient colonoscopy preparation and its association with hospital length of stay and costs. Dig Dis Sci. 2015; 60(11):3482-90.

Received September 15, 2016 